\title{
Adhesion of Lactobacillus isolates to intestinal epithelial cells of chicken
}

\begin{abstract}
A total of 46 Lactobacillus isolates obtained from chicken intestine were assessed on their ability to adhere to the chicken ileal epithelial cell (IEC) in vitro. Twelve out of the 46 isolates showed moderate to good ability to adhere to the IEC. Temperature (between $4{ }^{\circ} \mathrm{C}$ and $42^{\circ} \mathrm{C}$ ) did not affect attachment. Incubation (contact) time of $30 \mathrm{~min}$ was found to be insufficient for the attachment of bacteria to the IEC, but contact time beyond $1 \mathrm{~h}$ did not increase this ability. The $\mathrm{pH}$ values (4-7) of the suspending buffer did not have any significant effect on the attachment of bacteria to the IEC, but at $\mathrm{pH} 8$ it was reduced significantly $(\mathrm{P}<0.05)$.
\end{abstract}

Keyword: Lactobacillus; Chicken; Ileal epithelial cell 